\title{
Towards an understanding of the genetic basis behind 1080 (sodium fluoroacetate) tolerance and an investigation of the candidate gene $\mathrm{ACO} 2$
}

\author{
Janine E. Deakin ${ }^{\mathrm{A}, \mathrm{G}}$, Desmond W. Cooper ${ }^{\mathrm{B}}$, Jennifer J. Sinclair ${ }^{\mathrm{B}}$, Catherine A. Herbert ${ }^{\mathrm{C}}$, \\ Marilyn B. Renfree ${ }^{\mathrm{D}}$ and Matthew Wakefield ${ }^{\mathrm{E}, \mathrm{F}}$ \\ ADivison of Evolution, Ecology and Genetics, Research School of Biology, The Australian National University, \\ Canberra, ACT 0200, Australia. \\ ${ }^{B}$ School of Biological, Earth and Environmental Sciences, University of New South Wales, Sydney, NSW 2052, \\ Australia. \\ CFaculty of Veterinary Science, The University of Sydney, NSW 2006, Australia. \\ Department of Zoology, The University of Melbourne, Melbourne, Vic. 3010, Australia. \\ Eioinformatics Division, The Walter and Eliza Hall Institute of Medical Research, Parkville, Vic. 3052, Australia. \\ FDepartment of Genetics, The University of Melbourne, Melbourne, Vic. 3010, Australia. \\ ${ }^{\mathrm{G}}$ Corresponding author. Email: janine.deakin@anu.edu.au
}

\begin{abstract}
Sodium fluoroacetate, commonly referred to as 1080 , is a pesticide heavily used to control vertebrate pests. The development of tolerance to this poison by target species is a critical concern raised by its intensive use. Tolerance to 1080 is common amongst many native vertebrates in south-west Western Australia and is thought to be the result of a long period of coevolution with plant species that produce 1080 in their seeds and flowers. Among those vertebrate species tolerant to 1080 exposure is a subspecies of the tammar wallaby (Macropus eugenii). Tammars from Western Australia are tolerant while the subspecies present on Kangaroo Island is susceptible to 1080 exposure. The availability of genetic and genomic information, combined with a distinct difference in tolerance to 1080 between subspecies, makes the tammar wallaby an ideal species in which to study the genetic basis behind 1080 resistance. To date, research in this area has focussed on a candidate gene approach. Since 1080 inhibits the action of the mitochondrial aconitase enzyme, the aconitase gene $A C O 2$ was considered a prime candidate for involvement in 1080 tolerance. However, sequencing of the full-length $A C O 2$ transcript failed to identify a sequence variant between the two subspecies that would result in an amino acid change in the active site of the enzyme. Future studies will need to take a genome-wide approach to identify the gene(s) responsible for 1080 tolerance.
\end{abstract}

Received 22 October 2012, accepted 3 May 2013, published online 23 May 2013

\section{Introduction}

Sodium fluoroacetate $\left(\mathrm{FCH}_{2} \mathrm{COONa}\right)$, also known as 1080 , is a highly toxic pesticide intensively used for the control of introduced vertebrate pests. It is the preferred poison used in baits for pest control in Australia and New Zealand because it poses less risk to non-target animals compared with other poisons such as strychnine, pindone and cyanide (Fleming et al. 2001). In New Zealand, 1080 has been used since the early 1950s in attempts to control the pest population of Australian brushtail possums (Trichosurus vulpecula) (Montague 2000) as well as the introduced Bennett's (Macropus rufogriseus rufogriseus) and tammar (Macropus eugenii) wallaby populations (Eason et al. 2010). 1080 has been used in Australia for many years to control introduced species such as rabbits (Oryctolagus cuniculus), red foxes (Vulpes vulpes) (Saunders et al. 2010), pigs (Sus scrofa) (Twigg et al. 2005) and wild dogs (Fleming et al. 2001) and native species in Tasmania, such as common brushtail possums, Tasmanian pademelons (Thylogale billardierii) and Bennett's wallabies (McIlroy 1982a). One of the concerns raised by the intensive use of this poison is the development of resistance in target species. In fact, resistance to 1080 has already been reported for rabbits in Western Australia (Twigg et al. 2002). The development of resistance in target species could have major implications for vertebrate pest control programs, as well as agriculture in regions using 1080.

Many native vertebrates in Western Australia are more tolerant of 1080 exposure than their eastern Australia conspecifics. Native animals in the south-west of Western Australia have coexisted with fluoroacetate-bearing vegetation for long periods and have developed varying levels of tolerance to 1080 (Twigg et al. 2003). Plants in this region belonging to the genera Gastrolobium, Oxylobium and Acacia produce sodium 
monofluoroacetate as a defence against over-browsing (Twigg and King 1991). The toxic nature of these plants on livestock was recognised in the mid-1800s yet it was apparent that native vertebrate species that fed on these plant species were tolerant (Cameron 1977). Such plants are absent in eastern Australia and native animals outside of Western Australia do not have 1080 tolerance. Differences in tolerance to 1080 between populations in south-west Western Australian and other parts of Australia have been reported for many species, including mammals, reptiles and birds (Oliver et al. 1977, 1979; King et al. 1978; McIlroy 1981, 1982a, 1982b; Mead et al. 1985; Twigg and King 1989, 1991; Twigg and Mead 1990; Martin and Twigg 2002; Twigg et al. 2003). The genetic basis for this difference in tolerance is currently unknown but it is clear that it is a genetic trait (Oliver et al. 1979).

Fluoroacetate inhibits the tricarboxylic acid (TCA) cycle, resulting in an accumulation of citrate in plasma and tissues. Plasma citrate accumulation has been used for many years to quantify the difference in fluroacetate tolerance between eastern and western conspecifics and to estimate the $\mathrm{LD}_{50}$ (lethal dose required to kill $50 \%$ of the test species) (reviewed in Twigg and King 1991). Tolerance differences have been detected between eastern and western races of reptiles and birds, as well as several marsupial and eutherian mammals (Table 1). The high tolerance of native species has been exploited in successful fox control programs in Western Australia to enhance conservation efforts for several threatened species, such as the southern brown bandicoot (Isoodon obesulus) (Green 2004) and the black-flanked rock wallaby (Petrogale lateralis) (Kinnear et al. 1998).

Cooper and Herbert (2001) expressed concern over repeated use of pesticides such as 1080, making it clear that, in terms of population genetics, the potential selection for resistance to a pesticide would be strong. This is an understudied area of 1080 population control programs but, in light of the rapid detection of rodents resistant to rodenticides (Boyle 1960), and the ecological and economic consequences that 1080 resistance would have for Australia and New Zealand, it is an area of research that should receive more attention. Cooper also recognised the value of the tammar wallaby (Macropus eugenii) as a model species for uncovering the genetic basis behind 1080 tolerance. Thanks in large part to his efforts to establish a pedigreed colony of tammar wallabies (McKenzie et al. 1993), this species has been extensively used for research into marsupial genetics and genomics (Renfree et al. 2011). The geographic populations of tammars, which have been isolated for at least 10000 years, are restricted to off-shore islands and the mainland of south-west Western Australia, and Kangaroo Island off the coast of South Australia. Western Australian and Kangaroo Island populations are classified as separate subspecies. The Kangaroo Island animals are far more susceptible to 1080 than are their Western Australian counterparts (Oliver et al. 1979). Many genetic polymorphisms have been detected between the two subspecies (Zenger et al. 2002; Wang et al. 2011a) and the genome of a Kangaroo Island individual has recently been sequenced (Renfree et al. 2011). Thus, the tammar wallaby is a good choice of species in which to investigate the genetics behind 1080 tolerance.

\section{Elucidating the genetic basis of 1080 tolerance}

By considering the phenotype of tolerant animals we are able to deduce the likely mechanisms by which tolerance is occurring. The mechanisms by which resistance to a selective agent can occur include: reduced absorption, increased excretion, detoxification, mutation of a molecular target, and metabolic pathway compensation. The observations of the 1080 phenotype show that tolerance is present when 1080 is administered by nonoral routes (e.g. intraperitoneal injection) to tammar wallabies, western grey kangaroos (Macropus fuliginosus) and bush rats (Rattus fuscipes) (Oliver et al. 1979). Species that are resistant to 1080 are also known to retain a secondary toxicity to predators (McIlroy and Gifford 1991; Gillies and Pierce 1999). Although direct tissue distribution measurements are not available, these findings suggest that resistant species retain sufficient fluoroacetate or fluorocitrate metabolite in the consumed tissues to be toxic to the carnivore. These observations are consistent with a mutation of the molecular target of the poison or a metabolic pathway compensation rather than reduced absorption, increased excretion or detoxification being the primary mechanism of the tolerance observed in wild populations.

Table 1. Species with detectable differences in $\mathbf{1 0 8 0}$ tolerance between western and eastern Australian individuals From Twigg and King (1991). $\mathrm{LD}_{50}$ given as $\mathrm{mg} 1080 \mathrm{~kg}^{-1}$

\begin{tabular}{llcc}
\hline Species & Common name & $\begin{array}{c}\text { Western } \\
\text { race } \mathrm{LD}_{50}\end{array}$ & $\begin{array}{c}\text { Eastern } \\
\text { race } \mathrm{LD}_{50}\end{array}$ \\
\hline $\begin{array}{l}\text { Reptiles } \\
\quad \text { Tiliqua rugosa } \\
\quad \text { Varanus rosenbergi }\end{array}$ & Shingleback & $\geq 500$ & 214 \\
$\begin{array}{l}\text { Birds } \\
\quad \text { Phaps chalcoptera }\end{array}$ & Heath monitor & $200-300$ & 40 \\
Marsupials & Common bronzewing & 40 & 25 \\
$\quad$ Antechinus flavipes & Yellow-footed Antechinus & 12.5 & 3.5 \\
$\quad$ Isoodon obesulus & Southern brown bandicoot & 20 & 7 \\
$\quad$ Macropus eugenii & Tammar wallaby & $\geq 5$ & 0.3 \\
$\quad$ Trichosurus vulpecula & Common brushtail possum & 125 & 0.75 \\
Eutherians & Bush rat & $20-80$ & 1.1 \\
$\quad$ Rattus fuscipes & Dusky field rat & $\geq 5$ & 0.3 \\
Rattus sordidus & & & \\
\hline
\end{tabular}


To identify the molecular basis of 1080 tolerance it is useful to understand how resistance develops in a laboratory setting, and the broader theory of resistance evolution in other contexts such as insecticide resistance. Laboratory-based experiments have demonstrated the ability to induce 1080 resistance at 7-fold levels over 25 generations in flies (Musca domestica) and 1.8-fold over five generations in rats (Tahori 1963; Howard et al. 1973). These data demonstrate that in these species 1080 resistance is a selectable trait; however, it does not indicate whether the observed resistance is monogenic or polygenic in origin. From work on insecticide resistance it is suggested that acute doses that are lethal will favour single mutational events, for example mutations in the active enzyme site (McKenzie and Batterham 1994). Often mutations in the same gene are observed in different populations and even in different species. An example of this in vertebrates would be the development of resistance to anticoagulants used to control rodents. The use of such rodenticides started in the 1950 s and it was later that same decade that individuals resistant to the poison were identified (Boyle 1960). This resistance has been attributed to amino acid changes in the VKORC1 gene encoding for vitamin $\mathrm{K}$ reductase complex subunit 1 , which is a target enzyme of these poisons (Rost et al. 2004). Several different mutations in this gene have been detected in independent populations of rodents (Pelz et al. 2005; Grandemange et al.2010), all of which are capable of conferring resistance (Hodroge et al. 2011). In contrast, low-dose long-term selection, as may occur with the natural occurrence of sodium monofluoroacetate in the field, may favour a collection of more subtle changes that act together, along with the evolution of compensatory changes that ameliorate the otherwise deletrious effects of resistance mutations (McKenzie and Batterham 1994). These types of mutations are often specific to particular populations.

The toxicity of 1080 is the result of inhibition of aerobic production of energy of the mitochondrial aconitase enzyme (EC 4.2.1.3) (Goncharov et al. 2006). This enzyme catalyses the interconversion of citrate to isocitrate in the TCA cycle. Although aconitase is a mitochondrial enzyme, it is encoded by a nuclear gene called aconitase 2 (ACO2), making it a prime candidate for investigating the genetic basis of 1080 tolerance. To determine whether $A C O 2$ plays a role in tolerance to 1080 , we examined the effect of 1080 on aconitase activity in the white blood cells of tolerant and susceptible subspecies of the tammar wallaby as well as subspecies hybrids. White blood cells were chosen because they can be obtained repeatedly without killing the animals. We also sequenced most of the $A C O 2$ gene transcript from Western Australian and South Australian tammar wallabies in order to determine whether tolerance to 1080 was due to sequence differences in the candidate gene $A C O 2$. This investigation is a first step towards defining the genetic basis of tolerance to 1080 .

\section{Materials and methods}

\section{Study animals}

M. eugenii derbianus was collected from Tutanning Nature Reserve (mainland Western Australia -WA), Abrolhos Island (AI) and Garden Island (GI) in the south-west of Western Australia. M. eugenii decres was collected from Kangaroo Island (KI), which is located in South Australia. Crosses between the two subspecies were bred in captivity. The wallabies were housed in outdoor grassy yards at either the Cowan Field Station, a University of New South Wales field facility, or The University of Melbourne captive colony. Water and commercial kangaroo pellets, or lucerne hay, were provided ad libitum. All sampling was done with the approval of the University of New South Wales Animal Care and Ethics Committee (05/25B and 05/26B) and The University of Melbourne Animal Ethics Committee.

\section{Sample collection for aconitase assay}

Blood samples $(8-10 \mathrm{~mL})$ were collected from individuals (Total $n=36$; Tutanning $n=9$, Garden Island $n=3$, Kangaroo Island $n=18$, and hybrids $n=6$ ) by venipuncture of a lateral tail vein using syringes containing $0.5 \mathrm{~mL}$ Heparin (DBL, Melbourne, Australia) to prevent clotting. White blood cells were isolated using LeucoSep separation tubes (Greiner bio-one, Frickenhausen, Germany) and Ficoll-Paque PLUS (Amersham Biosciences, Uppsala, Sweden). Isolation procedures were performed according to the protocol supplied with the LeucoSep separation tubes. Cell counts were conducted using a haemocytometer by viewing isolated cells stained with a $1: 2$ dilution of Trypan blue (Sigma, Castle Hill, Australia) under a microscope.

\section{Aconitase assay}

White cells were assayed for aconitase activity by spectrophotometrically measuring the production of NADPH based on the methods of Morrison (1954) and Gardner et al. (1994). After isolation, white cell concentrations were adjusted to $2-3 \times 10^{5}$ cells $\mathrm{mL}^{-1}$ for the aconitase assays. The cells were incubated for $1 \mathrm{~h}$ at $35^{\circ} \mathrm{C}$ in $100 \mathrm{~mm}$ Tris buffer. The samples then underwent four rapid freeze-thaw cycles by storing them for $10 \mathrm{~min}$ at $-80^{\circ} \mathrm{C}$ and returning them to $35^{\circ} \mathrm{C}$. Thawed cell solutions were promptly assayed for aconitase activity by following the linear absorbance change at $340 \mathrm{~nm}$ (NADPH wavelength) using a spectrophotometer (Cary 100 UV-Visible spectrophotometer, Varian Inc., Australia) for $30 \mathrm{~min}$ at $22^{\circ} \mathrm{C}$ in a 3-mL reaction mix containing $36 \mathrm{mmol}$ Tris $\mathrm{pH}$ 7.4, $0.07 \mathrm{mmol}$ citric acid, $0.18 \mathrm{mmol} \beta$-nicotinamide adenine dinucleotide phosphate, $1.3 \mathrm{mmol}$ manganese sulfate, 0.7 units isocitric dehydrogenase (NADP + dependent) and $7.8 \mathrm{~mm}$ sodium fluoracetate. Positive control assays excluding sodium fluoroacetate were set up in the same manner. Samples containing only white blood cells and sterile Milli-Q water were also assayed as a negative control. The reagents in the reaction mixture were all obtained from Sigma (Castle Hill, Australia).

The change in linear absorbance at $340 \mathrm{~nm}$ can be used to calculate the amount of isocitrate formed by the catalysis of isocitrate dehydrogenase. The amount of NADPH produced in the reaction is stoichiometric with the amount of isocitrate produced as a result of aconitase activity (Pallanca et al. 1989). One milliunit $\mathrm{mL}^{-1}$ of enzyme catalyses the formation of $1 \mathrm{nmol} \mathrm{mL}{ }^{-1}$ of isocitrate based on the following equation: $\mathrm{nmol} \mathrm{mL} L^{-1}$ of isocitrate formed $=\left[\left(\Delta \mathrm{A}_{340 \mathrm{~nm}} / \mathrm{min}\right.\right.$ Test $-\Delta \mathrm{A}_{340 \mathrm{~nm}} /$ $\min$ Blank $\left.)\left(\mathrm{V}_{\mathrm{F}}\right)(\mathrm{df}) /(6.22)\left(\mathrm{V}_{\mathrm{ISO}}\right)\right] \times 1000$, where $\mathrm{V}_{\mathrm{F}}$ is the final volume of the assay $\left(\mathrm{V}_{\mathrm{F}}=3 \mathrm{~mL}\right)$, df is the dilution factor $(\mathrm{df}=1)$, and $\mathrm{V}_{\text {ISO }}$ is the volume of isocitrate dehydrogenase used in the assay $\left(\mathrm{V}_{\mathrm{ISO}}=0.1 \mathrm{~mL}\right) .6 .22$ is the millimolar extinction coefficient of $\beta$-NADPH at $340 \mathrm{~nm}$. 


\section{Sample collection for RNA extraction}

Blood samples $(\sim 5 \mathrm{~mL})$ were collected from individuals (WA $n=2$, KI $n=1$, AI $n=1$, KI/WA hybrids $n=3$, KI/GI hybrids $n=2$ ) by venipuncture of a lateral tail vein and transferred into EDTA-containing tubes. Samples were either transferred directly into RNAlater (Ambion, Austin, TX, USA) as whole blood for transportation and storage or white blood cells were first separated from other blood components by centrifugation and then stored in RNAlater (Ambion) at $-20^{\circ} \mathrm{C}$ until the RNA extraction process was performed.

\section{ACO2 transcript sequencing}

RNA was extracted from white blood cells using the RiboPure kit (Ambion) according to the manufacturer's instructions. Any contaminating genomic DNA present in the resulting RNA was removed by DNase treatment with the DNA-free DNase kit (Ambion) following the manufacturer's protocol. The quality and quantity of RNA extractions was determined spectrophotometrically and RNA integrity was tested by running all samples on a $1.2 \%$ denaturing formaldehyde agarose gel (Sambrook et al. 1989). First-strand synthesis of cDNA was performed on $1 \mu \mathrm{g}$ of total RNA with GeneRacer Oligo dT primer (Invitrogen, Carlsbad, CA, USA) or random hexamers using the SuperScript III Reverse Transcriptase system (Invitrogen) according to the manufacturer's instructions. To ensure that there was no residual contaminating genomic DNA present in the cDNA samples, a RT-negative control reaction was set up for each sample where the Supercript III enzyme was excluded from the first-strand synthesis reaction and this was used as control in subsequent PCR amplification experiments.

Rapid amplification of cDNA Ends (RACE) was used to amplify the $5^{\prime}$ and $3^{\prime}$ untranslated regions of the gene in one individual. Nested primers (Table 2; Fig. 1a) were designed as close as possible to either end of the coding sequence. RACE was performed with the GeneRacer kit (Invitrogen) and by following

Table 2. Primers used for amplification of the tammar wallaby $\mathrm{ACO} 2$ gene

\begin{tabular}{llc}
\hline Primer Name & Sequence $\left(5^{\prime}\right.$ to $\left.3^{\prime}\right)$ & $\begin{array}{c}\text { Product } \\
\text { size (bp) }\end{array}$ \\
\hline 5'RACE_R1 & CCGAAGCCGCAGGTATGACTTGC & 241 \\
5'RACE_R2 & CCAGGTGACCATACACAATCTTCTCTG & \\
3'RACE_F1 & TCTAACAACCTGCTGATTGG & 792 \\
3'RACE_F2 & CAAGAGTTTGGTCCAGTGCCA & \\
ACO2_1F & ACAAAATGGCGCCGTATAAC & 402 \\
ACO2_1R & CGATCAAGTGGTCACAGTGG & \\
ACO2_2F & GCGCCGTATAACCTGCTG & 811 \\
ACO2_2R & GCCCATGGTACTCGACGAT & \\
ACO2_3F & CATCTGTATCGGGGTTGGTG & 806 \\
ACO2_3R & AGGAGGTGACGATGGTGTTC & 817 \\
ACO2_4F & GGGCTGAAATGCAAGTCTCA & \\
ACO2_4R & GTGGTTCCAGGGCTGCAT & 563 \\
ACO2_5F & CACGGATCACATCTCTGCTG & 767 \\
ACO2_5R & ACTGCTGCAGCTCCTTCATC & \\
ACO2_6F & ATGGGAAAGCCAATTCAGTG & \\
ACO2_6R & GACCTCCAGCCACCATTAAA & \\
\hline
\end{tabular}

(a)

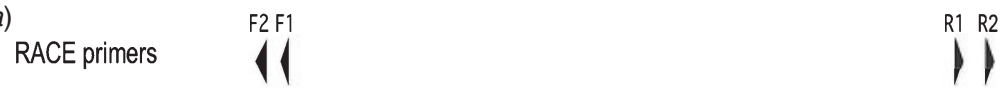

$\left.\right|^{R 1}$

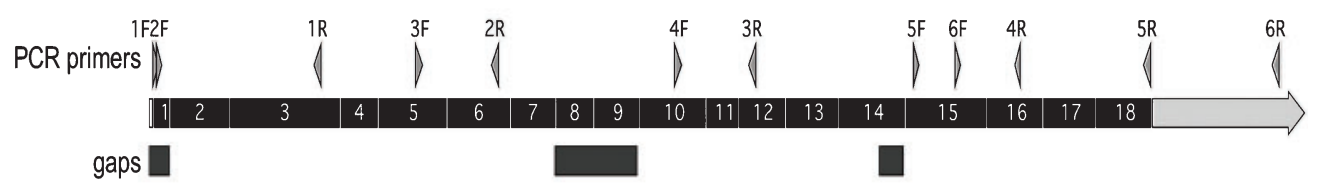

gaps

500

1000

1500

2500

(b)

(c)

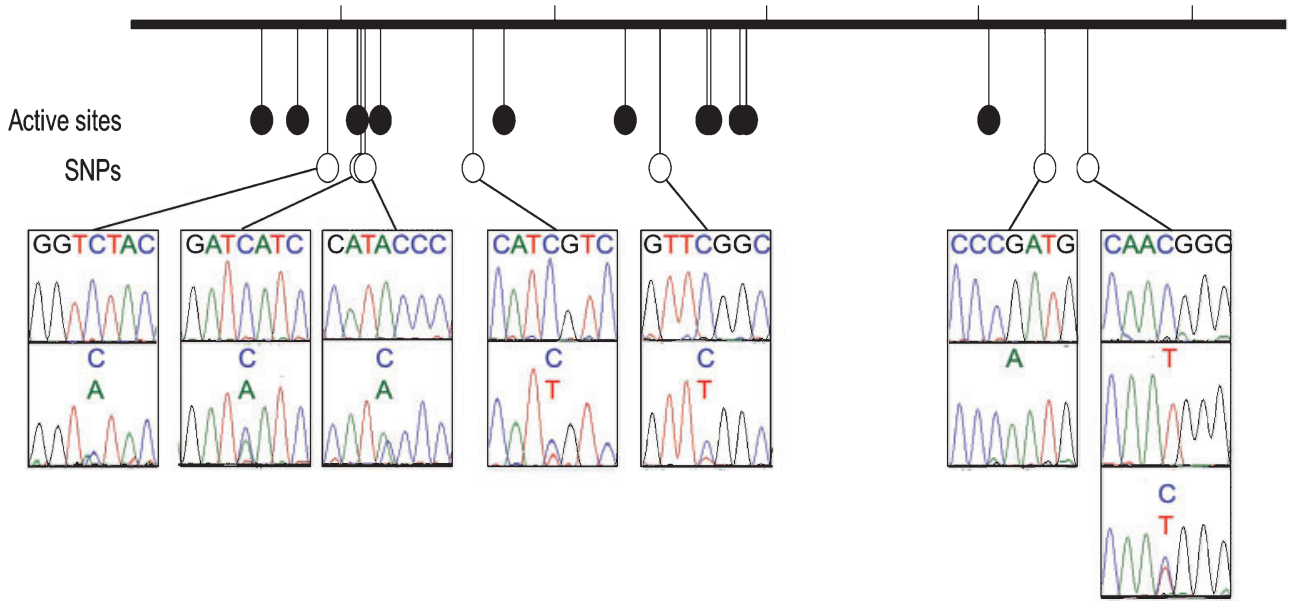

Fig. 1. (a) The tammar wallaby $A C O 2$ gene structure, including the size and position of the 18 exons (black) and the $5^{\prime}$ and $3^{\prime}$ untranslated regions (light grey). (b) Active sites (Mirel et al. 1998) within the enzyme are indicated by black circles and position of SNPs detected between the 10 sequenced individuals are shown. (c) Examples of sequence chromatograms for each SNP. 
the manufacturer's protocol. PCR amplicons were subjected to electrophoresis on a $1 \%$ agarose gel with TAE buffer and SYBR Safe DNA gene stain (Invitrogen). Resulting bands were excised from the gel and the DNA purified using the PureLink Quick Gel Extraction kit (Invitrogen). Purified DNA was sent to the Australian Genome Research Facility (AGRF) (Brisbane, Australia) for direct sequencing.

\section{BAC clone isolation and physical mapping}

Overgo probes for the tammar $A C O 2$ gene were designed from tammar genome sequence using the program OvergoMaker (available as a download from Washington University Genome Sequencing Center): ACO2_A 5'-CACTGACCTTGTCAGAG AAGATTG-3' and ACO2_B 5'-TCCAGGTGACCATACAC AATCTTC-3. These overgos were radioactively labelled and used to screen high-density tammar wallaby bacterial artificial chromosome (BAC) library filters (Me_KBa: Arizona Genomics Institute, Tuscon, AZ, USA) using the protocol previously described by Deakin et al. (2007). Resulting positive BACs were further screened using dot blots as previously detailed by Deakin et al. (2008). BAC DNA extracted using the Promega SV Wizard kit (Promega, Alexandria, NSW, Australia) was labelled with SpectrumOrange (Abbott Molecular Inc., Des Plaines, IL, USA) and hybridised to male tammar wallaby metaphase chromosomes as reported previously (Alsop et al. 2005). Unbound probe was removed using the washing procedure outlined in Deakin et al. (2008). DAPI-stained chromosome and fluorescent signal images were captured on a SPOT RT Monochrome CCD (chargecoupled device) camera (Diagnostic Instruments Inc., Sterling Heights, MI, USA) and merged using IP Laboratory imaging software (Scanalytics Inc., Fairfax, VA, USA).

\section{Polymorphism search within the ACO2 gene}

Primers for the amplification of $5^{\prime}$ and $3^{\prime}$ regions and the entire $A C O 2$ coding sequence from all individuals were designed from sequence obtained from RACE and sequence available from the tammar genome project (Renfree et al. 2011). Primer sequences and product sizes are listed in Table 2 and their position within the gene for the six primer pairs is shown in Fig. 1a. All PCR amplifications were performed in a $25-\mu$ l reaction volume with $200 \mathrm{ng}$ cDNA, $0.2 \mu \mathrm{M}$ of each primer, 1X PCR Buffer (Invitrogen), $0.2 \mathrm{~mm}$ of each dNTP, $1.5 \mathrm{mM} \mathrm{MgSO}_{4}$ and $0.2 \mu \mathrm{L}$ of Platinum Taq DNA polymerase High Fidelity (Invitrogen) and cycling conditions of an initial denaturing step of $95^{\circ} \mathrm{C}$ for $2 \mathrm{~min}$, followed by 35 cycles of $95^{\circ} \mathrm{C}$ for $30 \mathrm{sec}, 60^{\circ} \mathrm{C}$ for $30 \mathrm{~s}, 72^{\circ} \mathrm{C}$ for $90 \mathrm{~s}$, and concluded with a final extension cycle at $72^{\circ} \mathrm{C}$ for 10 min. PCR products were electrophoresed on a $1 \%$ agarose gel with $1 \mathrm{X}$ TAE. Bands were excised from the gel, DNA extracted and sent for direct sequencing at AGRF. All bands were sequenced twice in both directions. Sequences were trimmed of any poor-quality sequence so that at least $90 \%$ of the sequence analysed had a high confidence value, as indicated by Sequencher software ver. 4.10.1 (Gene Codes Corporation, Ann Arbor, MI, USA). Single nucleotide polymorphisms (SNPs) were detected by manually examining the sequence in Sequencher and were scored as a SNP only if detected on both strands and/or in sequence from overlapping PCR products.

\section{Results and discussion}

Mitochrondrial aconitase tissue culture assay

The effect of 1080 on mitochrondrial aconitase activity was examined using an in vitro tissue culture assay. This assay was designed to measure the production of isocitrate in the presence of 1080 in white blood cells of tolerant and sensitive subspecies of tammar wallaby and of hybrids between them. This assay enabled the hypothesis that mitochondrial aconitase in cells of Western Australian tammar wallabies is more tolerant to 1080 than is aconitase in South Australian tammar wallabies to be tested. Differences in the effect of 1080 on mitochondrial aconitase from the two different subspecies were detected, which correlate with their degree of tolerance (Fig. 2). The fact that the hybrids also exhibit tolerance implies that it may be a dominant characteristic.

\section{Sequencing and mapping of tammar wallaby ACO2}

With data indicative of differences in mitochondrial aconitase activity between 1080 tolerant and sensitive populations, the next logical step for elucidating the genetic basis of tolerance was to examine the $A C O 2$ gene for changes in amino acid sequence in active sites of the aconitase enzyme. The $A C O 2$ gene has been partially sequenced as part of the tammar wallaby genome project (Renfree et al. 2011). An individual from Kangaroo Island was used for the sequencing project. The Ensembl genebuild for this species (http://www.ensembl.org/Macropus_eugenii/Info/ Index) places $A C O 2$ on genescaffold_8869, flanked by genes PHF5A and POLR3H as it is in most vertebrates. However, the fragmented nature of the tammar genome sequence left gaps in the sequence, resulting in an inaccurate gene prediction. We have been able to fill these sequence gaps by amplifying and sequencing the cDNA for this gene from the tammar wallaby and provide accurate information on the structure of this gene.

We identified an additional $296 \mathrm{bp}$ of transcript sequence not found in the tammar genome assembly, including the first exon (36 bp), 198 bp spanning Exons 8 and 9 and 62 bp of Exon 14 (Fig. 1a). The coding region of wallaby ACO2 is actually $2349 \mathrm{bp}$ (GenBank Acession HQ646994) and encodes for a deduced 782 amino acid protein. Sequence similarity at the nucleotide level with other vertebrate species ranges from $80 \%$ (chicken and opossum) to $85 \%$ (cow) and sequence identity at the amino acid level ranges from $90 \%$ with chicken to $93 \%$ (opossum, human, mouse, cow). In addition, we used RACE to obtain the $5^{\prime}$ and $3^{\prime}$ untranslated regions of the wallaby $A C O 2$ gene. The $12 \mathrm{bp}$ of the $5^{\prime}$ UTR were also not present in the tammar genome sequence, most likely falling in a sequencing gap. The $3^{\prime} \mathrm{UTR}$ is $363 \mathrm{bp}$ and most of this sequence is present in the genome assembly.

The location of a BAC clone (MeKBa_455G18), isolated from the tammar wallaby BAC library and confirmed to contain the ACO2 gene, was determined using fluorescence in situ hybridisation. The BAC clone mapped to the long arm of Chromosome 3 (Fig. 3 ) in a region previously shown to contain genes from human Chromosome 22 (Renfree et al. 2011), the human chromosome on which $A C O 2$ is located.

\section{Search for polymorphisms in the ACO2 transcript}

The entire coding region and most of the untranslated region from nine individuals was sequenced. Sequence data from the 


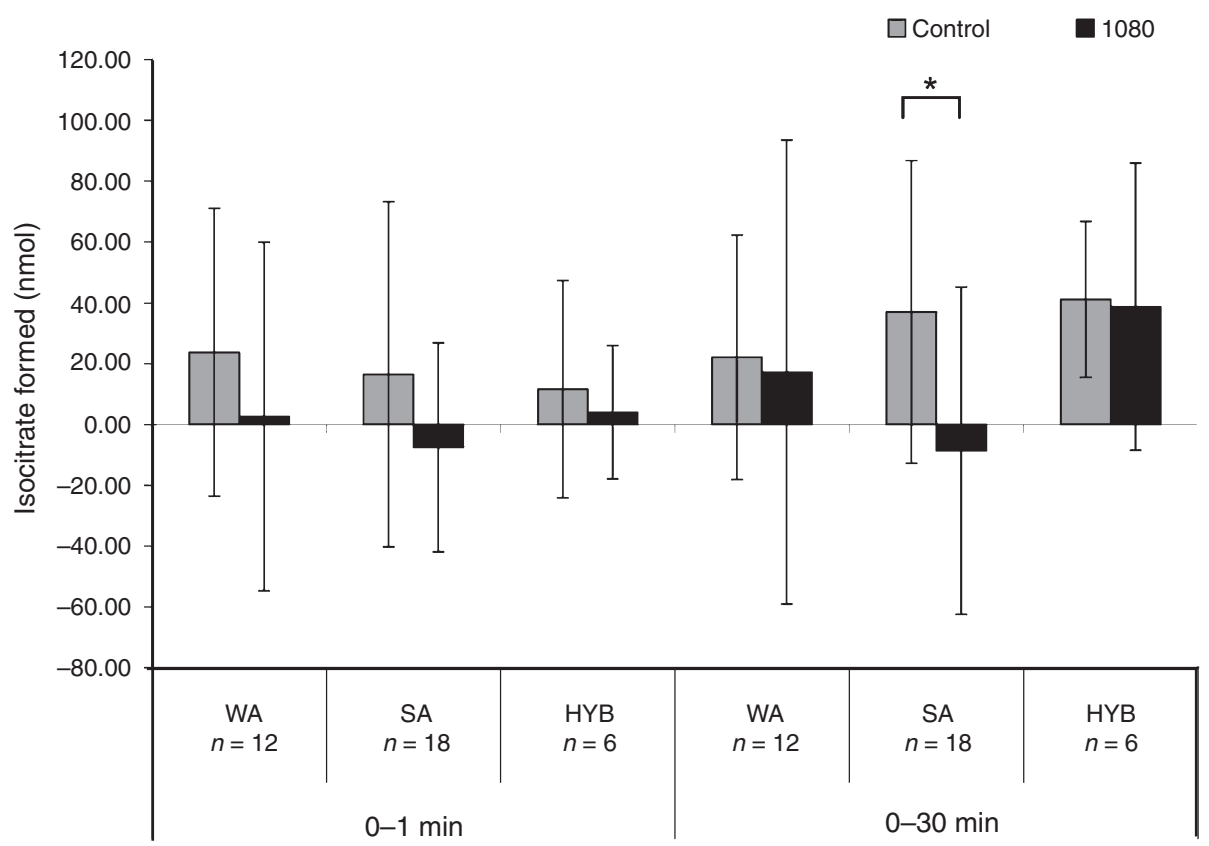

Fig. 2. A comparison of overall mitochondrial aconitase enzyme activity between Western Australian (WA), South Australian (SA) and hybrid (HYB) individuals for the 0-1-min and 0-30-min periods (when aconitase activity was at its greatest). The columns indicate the mean amount of isocitrate formed ( \pm s.d.) in experimental assays containing 1080 and in control assays where 1080 was absent. Isocitrate production was inhibited by the presence of 1080 for SA tammar wallaby samples for the $0-30$-min period $\left(t=2.309, P=0.034^{*}\right)$ and inhibition was also suggested for the $0-1$-min period $(t=1.409, P=0.06)$. No inhibition was detected for WA $(0-1$ min: $t=1.409, P=0.187 ; 0-30 \mathrm{~min}: t=0.356, P=0.725)$ or hybrid $(0-1 \mathrm{~min}: t=0.478, P=0.653 ; 0-30 \mathrm{~min}: t=0.124$, $P=0.906)$ tammar wallaby white blood cell samples.

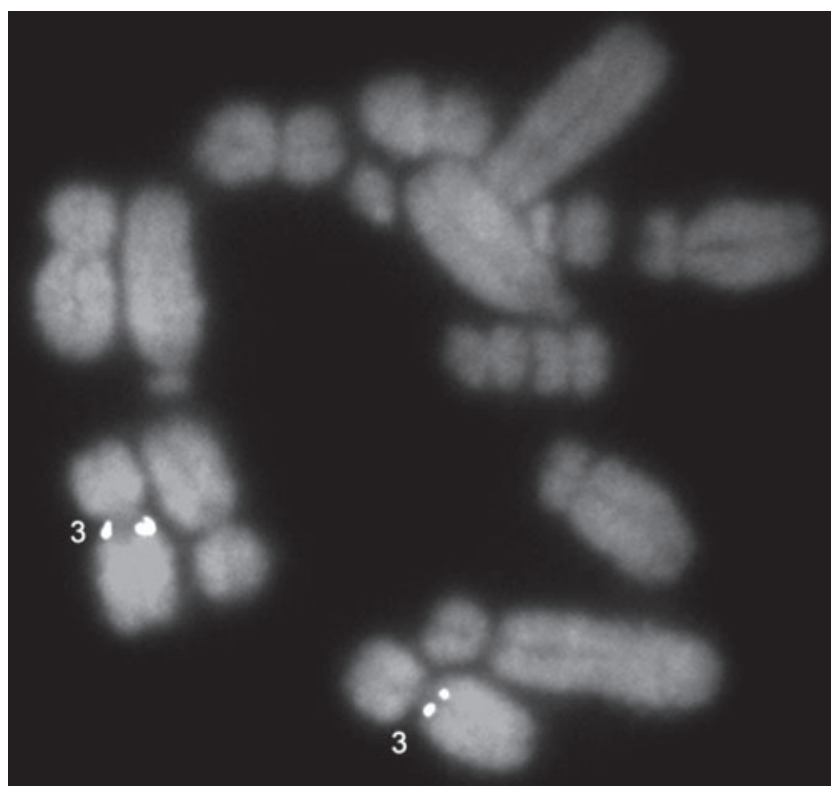

Fig. 3. ACO2-containing BAC physically mapped by FISH to the long arm of tammar wallaby chromosome 3 .

individual used for the genome project (Renfree et al. 2011) provided a second representative of a Kangaroo Island tammar wallaby. Only seven SNPs were detected in the $2653 \mathrm{bp}$ of $A C O 2$ sequenced across all individuals (Fig. 1b,c; Table 3). All except one SNP were synonymous substitutions and the only SNP to result in an amino acid change was located at nucleotide position 2256 (either GAT - aspartic acid, or AAT - asparagine). Variation at this nucleotide position was not restricted to either subspecies, nor was it located near an active site in the aconitase enzyme (Fig. 1b).

Sequencing of $A C O 2$ transcripts failed to uncover any sequence variation with a likely role in tolerance in Western Australia tammar wallabies. It could be argued that not enough individuals were examined to completely rule out an amino acid difference between the tammar wallaby subspecies. However, toxicology studies on these subspecies showed that all mainland Western Australian animals survived low to high doses of 1080 exposure (12 wallabies in total), whereas Kangaroo Island wallabies did not survive except when given the lowest dose (Oliver et al. 1979). This suggests that most of the Western Australian tammar wallaby population are resistant to 1080 .

Although differences in response to 1080 appear not to be due to amino acid changes in the $A C O 2$ gene, changes in regulation and the quantity of aconitase produced may be responsible for tolerance. Altered regulation could be caused by variants in the trans acting regulatory genes, or may be caused by variations in cis acting gene regulatory target sequences around the $\mathrm{ACO} 2$ gene. Regulatory sequences can be located some distance from the gene or within the gene's introns and affect the level of transcription of the gene. Unfortunately, the depth of sequence coverage in the tammar wallaby genome assembly is too low to 
Table 3. Genotypes of single nucleotide polymorphisms (SNPs) detected in the $A C O 2$ transcript sequence for each of the 10 individuals tested KI, Kangaroo Island; WA, Western Australia; AI, Abrolhos Islands; GI, Garden Island; KI.WA or KI.GI, hybrids

\begin{tabular}{|c|c|c|c|c|c|c|c|}
\hline \multirow{2}{*}{ Individual } & \multicolumn{7}{|c|}{ SNP Position within $A C O 2$} \\
\hline & 468 & 546 & 566 & 810 & 1205 & 2155 & 2256 \\
\hline KI-1 & $\mathrm{C} / \mathrm{C}$ & $\mathrm{C} / \mathrm{C}$ & $\mathrm{A} / \mathrm{A}$ & $\mathrm{C} / \mathrm{C}$ & $\mathrm{A} / \mathrm{A}$ & $\mathrm{G} / \mathrm{G}$ & $\mathrm{C} / \mathrm{T}$ \\
\hline $\mathrm{KI}-2$ & $\mathrm{C} / \mathrm{C}$ & $\mathrm{C} / \mathrm{C}$ & $\mathrm{A} / \mathrm{A}$ & $\mathrm{C} / \mathrm{C}$ & $\mathrm{A} / \mathrm{A}$ & $\mathrm{G} / \mathrm{G}$ & $\mathrm{T} / \mathrm{T}$ \\
\hline WA-1 & $\mathrm{C} / \mathrm{C}$ & $\mathrm{C} / \mathrm{C}$ & $\mathrm{A} / \mathrm{A}$ & $\mathrm{C} / \mathrm{T}$ & $\mathrm{A} / \mathrm{C}$ & $\mathrm{G} / \mathrm{G}$ & $\mathrm{T} / \mathrm{T}$ \\
\hline WA-2 & $\mathrm{C} / \mathrm{C}$ & $\mathrm{A} / \mathrm{C}$ & $\mathrm{A} / \mathrm{A}$ & $\mathrm{C} / \mathrm{C}$ & $\mathrm{A} / \mathrm{A}$ & $\mathrm{A} / \mathrm{A}$ & $\mathrm{C} / \mathrm{C}$ \\
\hline $\mathrm{AI}$ & $\mathrm{C} / \mathrm{C}$ & $\mathrm{C} / \mathrm{C}$ & $\mathrm{A} / \mathrm{A}$ & $\mathrm{C} / \mathrm{T}$ & $\mathrm{A} / \mathrm{C}$ & $\mathrm{A} / \mathrm{A}$ & $\mathrm{T} / \mathrm{T}$ \\
\hline KI.WA-1 & $\mathrm{A} / \mathrm{C}$ & $\mathrm{C} / \mathrm{C}$ & $\mathrm{A} / \mathrm{C}$ & $\mathrm{C} / \mathrm{C}$ & $\mathrm{A} / \mathrm{C}$ & $\mathrm{G} / \mathrm{G}$ & $\mathrm{T} / \mathrm{T}$ \\
\hline KI.WA-2 & $\mathrm{C} / \mathrm{C}$ & $\mathrm{C} / \mathrm{C}$ & $\mathrm{A} / \mathrm{A}$ & $\mathrm{C} / \mathrm{T}$ & $\mathrm{A} / \mathrm{C}$ & $\mathrm{G} / \mathrm{G}$ & $\mathrm{T} / \mathrm{T}$ \\
\hline KI.WA-3 & $\mathrm{C} / \mathrm{C}$ & $\mathrm{C} / \mathrm{C}$ & $\mathrm{A} / \mathrm{A}$ & $\mathrm{C} / \mathrm{C}$ & $\mathrm{A} / \mathrm{C}$ & $\mathrm{G} / \mathrm{G}$ & $\mathrm{C} / \mathrm{T}$ \\
\hline KI.G1-1 & $\mathrm{C} / \mathrm{C}$ & $\mathrm{C} / \mathrm{C}$ & $\mathrm{A} / \mathrm{A}$ & $\mathrm{C} / \mathrm{C}$ & $\mathrm{A} / \mathrm{A}$ & $\mathrm{G} / \mathrm{G}$ & $\mathrm{C} / \mathrm{T}$ \\
\hline KI.G1-2 & $\mathrm{C} / \mathrm{C}$ & $\mathrm{C} / \mathrm{C}$ & $\mathrm{A} / \mathrm{A}$ & $\mathrm{C} / \mathrm{C}$ & $\mathrm{A} / \mathrm{A}$ & $\mathrm{G} / \mathrm{G}$ & $\mathrm{C} / \mathrm{T}$ \\
\hline
\end{tabular}

completely cover the gene without sequence gaps, meaning that potentially important regulatory sequences may be missing from the genome assembly. The complete sequencing of the tammar wallaby BAC clone containing ACO2 could fill in any sequence gaps and facilitate the identification of potential regulatory elements.

\section{Future directions using genome-wide approaches}

1080 tolerance may be the result of mutations in hitherto unidentified genes interacting with $A C O 2$, or with other genes in the TCA cycle. For these reasons, a genome-wide search may be required to uncover the region(s) involved in 1080 resistance. Fortunately, a linkage map is available for the tammar wallaby which was constructed by using crosses between the two tammar wallaby subspecies (Zenger et al. 2002; Wang et al. 2011b). This, along with other genome resources available for the wallaby such as the genome sequence (Renfree et al. 2011), physical and integrated maps (Deakin 2010; Wang et al. 2011a), will make it possible to narrow down candidate regions or genes in future studies. In addition, the physical localisation of $A C O 2$ to Chromosome 3 will help determine whether $A C O 2$ is within a region segregating with 1080 tolerance.

Linkage mapping of 1080 tolerance in crosses between tolerant and sensitive populations remains one of the most promising approaches for identification of the gene or genes involved. Hybrids between the two tammar wallaby subspecies display tolerance in 1080 in the in vitro mitochondrial aconitase assay. Similarly, experiments on native rats indicate that the F1 hybrids have an intermediate phenotype (Twigg et al. 2003). This indicates that tolerance may be due either to a dominant or codominant single gene, or that tolerance is a cumulative effect of multiple loci. To investigate the inheritance pattern a substantial number of backcross animals (1080 tolerant F1s mated to sensitive population) would be required to be quantitatively phenotyped for their resistance status and genotyped with microsatellites.

We pursued the approach of developing a cell culture-based aconitase assay as this provides the advantage of being able to quantitatively determine the response for a single animal in vitro while maintaining the individual in the breeding colony. However, given the absence of genotypic variation in the $\mathrm{ACO} 2$ gene, further validation of the relationship between the tissue culture aconitase and the whole animal tolerance phenotype may be required for future work.

Given the potential complexity of the inheritance, identification of the functional variant or variants that confer 1080 resistance will remain a complex task. To identify additional candidate genes, RNAseq analysis to compare tolerant and sensitive populations, and to look for potential induction of genes in response to 1080 , may be a useful approach. The most promising direction remains the generation of linkage candidate regions that will allow focussed analysis of whole genome resequencing which has become a valuable and cost effective tool since the completion of the tammar wallaby genome.

\section{Acknowledgements}

Some of the research presented here represents the work Des Cooper was pursuing towards the end of his career. His contribution to the tammar wallaby genome project, the development of a tissue culture assay and the linkage approach represent his substantial contributions to the field of 1080 tolerance. We thank Kia Bailey, James Cook and Jan Nedved for help with the University of New South Wales tammar wallaby colony, and Scott Brownlees and Bonnie Dopheide for help with the Melbourne University colony. We thank Becky Choi for her work on the tissue culture assay, Auda Eltahla for help with primer design, and Stephen Frankenberg for in silico identification of the $A C O 2$ sequence from the wallaby genome assembly. Work on 1080 resistance in the tammar wallaby was supported by an Australian Research Council Discovery Grant to DWC (DPO851844) and was also part of the work of the ARC Centre of Excellence for Kangaroo Genomics.

\section{References}

Alsop, A. E., Miethke, P., Rofe, R., Koina, E., Sankovic, N., Deakin, J. E., Haines, H., Rapkins, R. W., and Marshall Graves, J. A. (2005). Characterizing the chromosomes of the Australian model marsupial Macropus eugenii (tammar wallaby). Chromosome Research 13, 627-636. doi:10.1007/s10577-005-0989-2

Boyle, C. M. (1960). Case of apparent resistance of Rattus norvegicus Berkenhout to anticoagulant poisons. Nature 188, 517. doi:10.1038/ $188517 \mathrm{a} 0$

Cameron, J. M. R. (1977). Poison plants in Western Australia and colonizer problem solving. Journal of the Royal Society of Western Australia 59, $71-77$.

Cooper, D. W., and Herbert, C. A. (2001). Genetics, biotechnology and population management of over-abundant mammalian wildlife in Australasia. Reproduction, Fertility and Development 13, 451-458. doi:10.1071/RD01072 
Deakin, J. E. (2010). Physical and comparative gene maps in marsupials. In 'Marsupial Genetics and Genomics'. (Eds J. E. Deakin, P. D. Waters and J. A. M. Graves.) pp. 101-115. (Springer: Dordrecht.)

Deakin, J. E., Siddle, H. V., Cross, J. G., Belov, K., and Graves, J. A. (2007) Class I genes have split from the MHC in the tammar wallaby. Cytogenetic and Genome Research 116, 205-211. doi:10.1159/000098188

Deakin, J. E., Koina, E., Waters, P. D., Doherty, R., Patel, V. S., Delbridge, M. L., Dobson, B., Fong, J., Hu, Y., van den Hurk, C., Pask, A. J., Shaw, G., Smith, C., Thompson, K., Wakefield, M. J., Yu, H., Renfree, M. B., and Graves, J. A. (2008). Physical map of two tammar wallaby chromosomes: a strategy for mapping in non-model mammals. Chromosome Research 16, 1159-1175. doi:10.1007/s10577-008-1266-y

Eason, C. T., Shapiro, L., Adams, P., Hix, S., Cunningham, C., MacMorran, D., Statham, M., and Statham, H. (2010). Advancing a humane alternative to sodium fluoroacetate (1080) for wildlife management welfare and wallaby control. Wildlife Research 37, 497-503. doi:10.1071/ WR10060

Fleming, P., Corbett, L., Harden, R., and Thomson, P. (2001). 'Managing the Impacts of Dingoes and Other Wild Dogs.' (Bureau of Rural Sciences: Canberra.)

Gardner, P. R., Nguyen, D. D. H., and White, C. W. (1994). Aconitase is a sensitive and critical target of oxygen poisoning in cultured mammalian cells and in rat lungs. Proceedings of the National Academy of Sciences of the United States of America 91, 12248-12 252. doi:10.1073/ pnas.91.25.12248

Gillies, C. A., and Pierce, R. J. (1999). Secondary poisoning of mammalian predators during possum and rodent control operations at Trounson Kauri Park, Northland, New Zealand. New Zealand Journal of Ecology 23, 183-192.

Goncharov, N. V., Jenkins, R. O., and Radilov, A. S. (2006). Toxicology of fluoroacetate: a review, with possible directions for therapy research. Journal of Applied Toxicology 26, 148-161. doi:10.1002/jat.1118

Grandemange, A., Lasseur, R., Longin-Sauvageon, C., Benoit, E., and Berny, P. (2010). Distribution of VKORC1 single nucleotide polymorphism in wild Rattus norvegicus in France. Pest Management Science 66, 270-276. doi:10.1002/ps.1869

Green, W. (Ed.) (2004). 'The Use of 1080 for Pest Control; A Discussion Document.' (Animal Health Board and the Department of Conservation: Wellington, NZ.)

Hodroge, A., Longin-Sauvageon, C., Fourel, I., Benoit, E., and Lattard, V. (2011). Biochemical characterization of spontaneous mutants of rat VKORC1 involved in the resistance to antivitamin $\mathrm{K}$ anticoagulants. Archives of Biochemistry and Biophysics 515, 14-20. doi:10.1016/ j.abb.2011.08.010

Howard, W. E., Marsh, R. E., and Palmateer, S. D. (1973). Selective breeding of rats for resistance to sodium monofluoroacetate. Journal of Applied Ecology 10, 731-736. doi:10.2307/2401865

King, D. R., Oliver, A. J., and Mead, R. J. (1978). Adaptation of some Western Australian mammals to food plants containing fluoroacetate. Australian Journal of Zoology 26, 699-712. doi:10.1071/ZO9780699

Kinnear, J. E., Onus, M. L., and Sumner, N. R. (1998). Fox control and rockwallaby population dynamics - II. An update. Wildlife Research 25, 81-88. doi:10.1071/WR96072

Martin, G. R., and Twigg, L. E. (2002). Sensitivity to sodium fluoroacetate (1080) of native animals from north-western Australia. Wildlife Research 29, 75-83. doi:10.1071/WR00117

McIlroy, J. C. (1981). The sensitivity of Australian animals to 1080 Poison. 2. Marsupial and eutherian carnivores. Australian Wildlife Research 8, 385-399. doi:10.1071/WR9810385

McIlroy, J. C. (1982a). The sensitivity of Australian animals to 1080 poison. 3. Marsupial and eutherian herbivores. Australian Wildlife Research 9, 487-503. doi:10.1071/WR9820487

McIlroy, J. C. (1982b). The sensitivity of Australian animals to 1080 poison. 4. Native and introduced rodents. Australian Wildlife Research 9, 505-517. doi:10.1071/WR9820505
Mcllroy, J. C., and Gifford, E. J. (1991). Effects on nontarget animal populations of a rabbit trail-baiting campaign with 1080-Poison. Wildlife Research 18, 315-325. doi:10.1071/WR9910315

McKenzie, J. A., and Batterham, P. (1994). The genetic, molecular and phenotypic consequences of selection for insecticide resistance. Trends in Ecology \& Evolution 9, 166-169. doi:10.1016/0169-5347(94)90079-5

McKenzie, L. M., Collet, C., and Cooper, D. W. (1993). Use of a subspecies cross for efficient development of a linkage map for a marsupial mammal, the tammar wallaby (Macropus eugenii). Cytogenetics and Cell Genetics 64, 264-267. doi:10.1159/000133590

Mead, R. J., Oliver, A. J., King, D. R., and Hubach, P. H. (1985). The coevolutionary role of fluoroacetate in plant-animal interactions in Australia. Oikos 44, 55-60. doi:10.2307/3544043

Mirel, D. B., Marder, K., Graziano, J., Freyer, G., Zhao, Q. Q., Mayeux, R., and Wilhelmsen, K. C. (1998). Characterization of the human mitochondrial aconitase gene (ACO2). Gene 213, 205-218. doi:10.1016/ S0378-1119(98)00188-7

Montague, T. L. (2000). 'The Brushtail Possum: Biology, Impact and Management of an Introduced Marsupial.' (Manaaki Whenua Press: Lincoln.)

Morrison, J. F. (1954). The kinetics of the reactions catalyzed by aconitase. The Australian Journal of Experimental Biology and Medical Science 32, 867-876. doi:10.1038/icb. 1954.90

Oliver, A. J., King, D. R., and Mead, R. J. (1977). Evolution of resistance to fluoroacetate intoxication in mammals. Search 8, 130-132.

Oliver, A. J., King, D. R., and Mead, R. J. (1979). Fluoroacetate tolerance, a genetic marker in some Australian mammals. Australian Journal of Zoology 27, 363-372. doi:10.1071/ZO9790363

Pallanca, J. E., Denney, R. C., and Rose, G. A. (1989). The automated enzymic assay of D-isocitrate in human urine. Annals of Clinical Biochemistry 26, $78-82$.

Pelz, H. J., Rost, S., Hunerberg, M., Fregin, A., Heiberg, A. C., Baert, K., MacNicoll, A. D., Prescott, C. V., Walker, A. S., Oldenburg, J., and Muller, C. R. (2005). The genetic basis of resistance to anticoagulants in rodents. Genetics 170, 1839-1847. doi:10.1534/genetics.104.040360

Renfree, M. B., Papenfuss, A. T., Deakin, J. E., Lindsay, J., Heider, T., Belov, K., Rens, W., Waters, P. D., Pharo, E. A., Shaw, G., Wong, E. S., Lefevre, C. M., Nicholas, K. R., Kuroki, Y., Wakefield, M. J., Zenger, K. R., Wang, C., Ferguson-Smith, M., Nicholas, F. W., Hickford, D., Yu, H., Short, K. R., Siddle, H. V., Frankenberg, S. R., Chew, K. Y., Menzies, B. R., Stringer, J. M., Suzuki, S., Hore, T. A., Delbridge, M. L., Mohammadi, A., Schneider, N. Y., Hu, Y., O'Hara, W., Al Nadaf, S., Wu, C., Feng, Z. P., Cocks, B. G., Wang, J., Flicek, P., Searle, S. M., Fairley, S., Beal, K., Herrero, J., Carone, D. M., Suzuki, Y., Sugano, S., Toyoda, A., Sakaki, Y., Kondo, S., Nishida, Y., Tatsumoto, S., Mandiou, I., Hsu, A., McColl, K. A., Lansdell, B., Weinstock, G., Kuczek, E., McGrath, A., Wilson, P., Men, A., Hazar-Rethinam, M., Hall, A., Davis, J., Wood, D., Williams, S., Sundaravadanam, Y., Muzny, D. M., Jhangiani, S. N., Lewis, L. R., Morgan, M. B., Okwuonu, G. O., Ruiz, S. J., Santibanez, J., Nazareth, L., Cree, A., Fowler, G., Kovar, C. L., Dinh, H. H., Joshi, V., Jing, C., Lara, F., Thornton, R., Chen, L., Deng, J., Liu, Y., Shen, J. Y., Song, X. Z., Edson, J., Troon, C., Thomas, D., Stephens, A., Yapa, L., Levchenko, T., Gibbs, R. A., Cooper, D. W., Speed, T. P., Fujiyama, A., Graves, J. A., O’Neill, R. J., Pask, A. J., Forrest, S. M., and Worley, K. C. (2011). Genome sequence of an Australian kangaroo, Macropus eugenii, provides insight into the evolution of mammalian reproduction and development. Genome Biology 12(R81), 1-25. doi:10.1186/gb-2011-12-8-r81

Rost, S., Fregin, A., Ivaskevicius, V., Conzelmann, E., Hortnagel, K., Pelz, H. J., Lappegard, K., Seifried, E., Scharrer, I., Tuddenham, E. G., Muller, C. R., Strom, T. M., and Oldenburg, J. (2004). Mutations in VKORC1 cause warfarin resistance and multiple coagulation factor deficiency type 2. Nature 427, 537-541. doi:10.1038/nature02214

Sambrook, J., Maniatis, T., and Fritsch, E. F. (1989). 'Molecular Cloning: a Laboratory Manual.' (Cold Spring Harbor Laboratory: Cold Spring Harbor.) 
Saunders, G. R., Gentle, M. N., and Dickman, C. R. (2010). The impacts and management of foxes Vulpes vulpes in Australia. Mammal Review 40, 181-211. doi:10.1111/j.1365-2907.2010.00159.x

Tahori, A. S. (1963). Selection for a fluoroacetate resistant strain of house flies and investigation of its resistance pattern. Journal of Economic Entomology 56, 67-69.

Twigg, L. E., and King, D. R. (1989). Tolerance to sodium fluoroacetate in some Australian birds. Australian Wildlife Research 16, 49-62. doi:10.1071/WR9890049

Twigg, L. E., and King, D. R. (1991). The impact of fluoroacetate-bearing vegetation on native Australian fauna - a review. Oikos 61, 412-430. doi: $10.2307 / 3545249$

Twigg, L. E., and Mead, R. J. (1990). Comparative metabolism of, and sensitivity to, fluoroacetate in geographically separated populations of Tiliqua rugosa (Gray) (Scincidae). Australian Journal of Zoology 37, 617-626. doi:10.1071/ZO9890617

Twigg, L. E., Martin, G. R., and Lowe, T. J. (2002). Evidence of pesticide resistance in medium-sized mammalian pests: a case study with 1080 poison and Australian rabbits. Journal of Applied Ecology 39, 549-560. doi:10.1046/j.1365-2664.2002.00738.x

Twigg, L. E., Martin, G. R., Eastman, A. F., King, D. R., and Kirkpatrick, W. E. (2003). Sensitivity of some Australian animals to sodium fluoroacetate (1080): additional species and populations, and some ecological considerations. Australian Journal of Zoology 51, 515-531. doi:10.1071/ZO03040
Twigg, L. E., Lowe, T., and Martin, G. (2005). Sodium fluoroacetate residues and carcass degradation of free-ranging feral pigs poisoned with 1080 . Wildlife Research 32, 573-580. doi:10.1071/WR05026

Wang, C., Deakin, J. E., Rens, W., Zenger, K. R., Belov, K., Marshall Graves, J. A., and Nicholas, F. W. (2011a). A first-generation integrated tammar wallaby map and its use in creating a tammar wallaby first-generation virtual genome map. BMC Genomics 12(422), 1-12. doi:10.1186/14712164-12-422

Wang, C., Webley, L., Wei, K. J., Wakefield, M. J., Patel, H. R., Deakin, J. E., Alsop, A., Graves, J. A., Cooper, D. W., Nicholas, F. W., and Zenger, K. R. (2011b). A second-generation anchored genetic linkage map of the tammar wallaby (Macropus eugenii). BMC Genetics 12(72), 1-16. doi:10.1186/1471-2156-12-72

Zenger, K. R., McKenzie, L. M., and Cooper, D. W. (2002). The first comprehensive genetic linkage map of a marsupial: the tammar wallaby (Macropus eugenii). Genetics 162, 321-330.

Handling Editor: Paul Cooper 